\title{
Surface microlayer contamination and toxicity in the German Bight
}

\author{
John T. Hardy ${ }^{1}$, John Cleary ${ }^{2}$ \\ 'Huxley College of Environmental Studies, Institute of Environmental Toxicology and Chemistry, Western Washington \\ University, Bellingham, Washington 98225, USA \\ ${ }^{2}$ Plymouth Marine Laboratory, Prospect Place, West Hoe, Plymouth, Devon PL1 3DH, United Kingdom
}

\begin{abstract}
Samples of sea-surface microlayer and near-surface bulkwater were collected at 5 stations in the German Bight area of the North Sea and at Wilhelmshaven, Germany, during the Bremerhaven Workshop in March 1990. Samples were analyzed for concentrations of heavy metals, organotin and tributyltin (TBT) and tested for toxicity using 5 different bioassays. Results indicate that: (1) sea surface contamination is widespread and extends at least $100 \mathrm{~km}$ from shore, (2) the surface microlayer contains higher concentrations of metal and organometal contaminants and is more toxic to marine organisms than the subsurface bulkwater, (3) echinoderm larvae, molluscan bivalve larvae and copepod toxicity tests all represent feasible options for of fshore pollution assessment, (4) larval survival in bioassays was inversely related to the concentrations of several contaminant metals in the microlayer, (5) glass plate, screen and rotating drum samplers all collect samples which are similar in metal concentrations and toxicity, but the drum offers several operational advantages for routine sampling and monitoring of sea surface contamination, and (6) the threat of surface microlayer contamination to the recruitment of North Sea fisheries warrants further examination
\end{abstract}

\section{INTRODUCTION}

The sea surface represents a highly-productive, metabolically-active interface and a vital biological habitat (Hardy 1982, 1991). Pelagic fish eggs float at the surface by buoyancy due to their high lipid content (Zaitsev 1971, Hempel \& Weikert 1972, Eldridge et al. 1978, Shanks 1983). The sea surface is also an important concentration point for both natural biogenic organic films (Baier et al. 1974) and organic and metal contaminants (see review by Hardy 1982). The seasurface microlayer often contains high enrichments (microlayer concentration/bulk water concentration) of both natural and anthropogenic organics including chlorinated hydrocarbons, plastic particles, petroleumderived hydrocarbons, and combustion-derived polycyclic aromatic hydrocarbons (Hardy 1982). Concentrations of potentially toxic metals, orders of magnitude greater than U.S. Environmental Protection Agency water quality criteria standards, were found in the USA in the surface microlayer of Puget Sound, Washington (Hardy et al. 1985a, 1987a), Chesapeake
Bay (Hardy et al. 1990), Southern California (Cross et al. 1987) and elsewhere (Hardy 1982).

Large quantities of anthropogenic pollutants enter the North Sea by atmospheric deposition, riverine input and ocean dumping. Atmospheric inputs of $\mathrm{Cu}$, $\mathrm{Zn}, \mathrm{Pb}$ and $\mathrm{Cd}$ to the surface microlayer of the North Sea are estimated to exceed by one order of magnitude the combined input of the rivers Scheldt, Rhine and Meuse (Dehairs et al. 1982). Fish embryos exposed to microlayer samples from Heligoland Harbour showed reduced hatching success and an increase in larval abnormalities, while those exposed to water from $20 \mathrm{~cm}$ depth showed normal development (Kocan et al. 1987. Westernhagen et al. 1987).

Despite the demonstrated importance of the sea surface as both a vital biological nursery area and a concentration point for contaminants, spatial distributions or temporal trends in surface contaminants, or their impacts on the reproduction of valuable marine species, remain largely unknown.

Several recent studies have linked aquatic surface contamination with negative biological impacts (Cross 


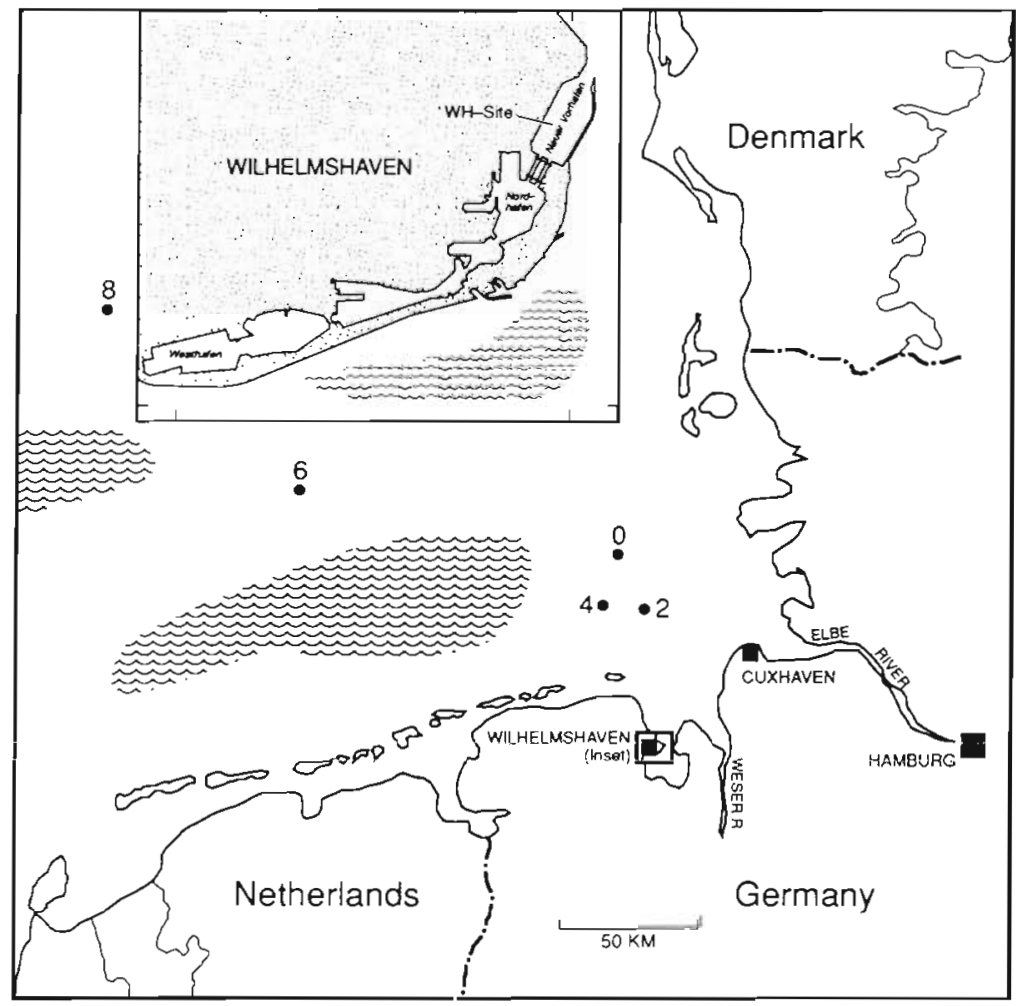

Fig. 1. Location of sampling stations in the North Sea

or a combination of the following: a rotating teflon drum (sample depth $34 \pm 18 \mu \mathrm{m}$; Hardy et al. 1988), a glass plate (sample depth 30 to $55 \mu \mathrm{m}$; Hardy et al. 1985a), or a stainless steel or nylon screen (sample depth 200 to $400 \mu \mathrm{m}$; Garrett 1965). Nearsurface bulkwater samples were collected by opening a bottle $0.5 \mathrm{~m}$ below the surface.

For trace metal analyses samples were dispensed into acid-cleaned bottles. For toxicity tests samples were returned to the ship and tests started within 24 h or, in the case of the echinoderm test, samples were frozen and returned to the laboratory for later testing.

Toxicity tests. We sought to evaluate the utility of several toxicity tests that would not require large volumes of sample or elaborate flow-through systems, yet might be sensitive in response, fairly rapid (96 h or less), and in general, convenient to conduct on board a vessel while at sea. With these criteria in mind, 3 general types of tests were evaluated: the echinoderm larvae (Hinegardner 1967, Oshida 1977), bivalve molluscan

et al. 1987 . Hardy et al. 1987 a, b); fish eggs exposed to contaminants exhibited reduced viability.

Our study was conducted as part of a larger interdisciplinary study of marine pollution in the North Sea (Stebbing et al. 1991). The objectives were to: (1) evaluate and compare several different methods of microlayer collection, (2) define the extent of aquatic surface microlayer contamination in the North Sea at nearshore and offshore sites, (3) compare the utility and sensitivity of several different toxicity bioassays for assessing offshore surface pollution, (4) compare the chemistry and toxicity of the microlayer to that of nearsurface bulkwater, and (5) examine possible relationships between toxicity and chemistry.

\section{METHODS}

Sample collection. Samples were collected during a cruise of the RV 'Valdivia' during March 1990 at 5 stations in the German Bight area of the North Sea (Fig. 1. Table 1). The outermost site was $470 \mathrm{~km}$ from the mouth of the Elbe River. To avoid local contamination from the ship, samples were collected at least $200 \mathrm{~m}$ upwind from the ship using a small boat driven by an electric motor Samples were also collected in the New Outer Harbour of Wilhelmshaven.

Microlayer samples were collected using either one larvae (ASTM 1980, Chapman \& Morgan 1983, Calabrese 1984), and copepod growth or survival (APHA 1989) tests. Microlayer or seawater samples were collected, brought onboard the ship and dispensed into replicate subsample containers. Fertilized eggs or young larvae were added to each subsample and incubated for $48 \mathrm{~h}$. The number of larvae surviving after $48 \mathrm{~h}$ or, in the case of the copepod, survival, development and increase in length (growth) after $96 \mathrm{~h}$ were recorded.

Toxicity bioassays were performed using freshly-fertilized embryos of the oyster Crassostrea gigas (for test details see Thain 1992). Replicate (2 to 5) subsamples were incubated and the percentage of larvae reaching the D-stage of development recorded. Bioassays were also performed using oyster Crassostrea gigas and

Table 1 Locations, dates and conditions at sampling sites

\begin{tabular}{|c|c|c|c|c|}
\hline \multirow[t]{2}{*}{ Site } & \multirow{2}{*}{$\begin{array}{c}\text { Date } \\
(1990)\end{array}$} & \multicolumn{2}{|c|}{ Location } & \multirow{2}{*}{$\begin{array}{c}\text { Wind } \\
\text { (Beaufort) }\end{array}$} \\
\hline & & Lat. N. & Long. E & \\
\hline Wilhemshaven & $23 \mathrm{Mar}$ & $53^{\circ} 33^{\prime}$ & $8^{\circ} 07^{\circ}$ & $6-7$ \\
\hline $\operatorname{Stn} 0$ & $16 \mathrm{Mar}$ & $54^{\circ} 13^{\prime}$ & $7^{\circ} 5 \pi$ & $3-4$ \\
\hline Stn 2 & $17 \mathrm{Mar}$ & $54^{\circ} 02^{\prime}$ & $8^{\circ} 03^{\circ}$ & $2.5-5.5$ \\
\hline Stn 4 & $17 \mathrm{Mar}$ & $54 \div 02^{\circ}$ & $7^{\circ} 50^{\prime}$ & $0-1$ \\
\hline Stn 6 & $18 \mathrm{Mar}$ & $54.25^{\circ}$ & $6 \cdot 14^{\prime}$ & $3-4$ \\
\hline $\operatorname{Stn} 8$ & $18 \mathrm{Mar}$ & $55^{\circ} 06^{\prime}$ & $5^{\circ} 00^{\prime}$ & 6 \\
\hline
\end{tabular}


clam Tapes philippinarum larvae which had been preserved and held in liquid nitrogen in an arrested state (cryo-preserved) (for test details see McFadzen 1992). Three hundred larvae per replicate were used, the number of surviving larvae in the first 50 larvae encountered in a subsample counted, and the percentage surviving after $48 \mathrm{~h}$ recorded.

The echinoderm bioassay was conducted using larvae of the sand dollar Dendrastes excentricus. Collected microlayer and bulkwater samples were frozen, returned to the laboratory, and thawed about 6 mo later for conducting the toxicity tests. No difference was found between controls using fresh or frozen-andthawed control seawater from a relatively pristine site near Anacortes, Washington, USA. For each sample collected, 4 replicate subsamples were tested using approximately 50 embryos per replicate. After $48 \mathrm{~h}$, the larvae were preserved in $5 \%$ buffered formalin and later examined microscopically. The number of larvae reaching the normal pluteus stage of development were recorded and normalized as percentages compared to the controls ( $89 \%$ of which reached pluteus).

Freshly collected microlayer and bulkwater samples were evaluated for toxicity using the harpacticoid copepod Tisbe battagliai (for test details see Williams 1992). Twenty nauplii (offspring) were exposed to each collected microlayer and bulkwater sample. Survival, development of the nauplius to the copepodid stage and lengths for each individual were recorded after 96 h exposure.

Chemical analyses. For organotins a 21 water sample was acidified with $50 \mathrm{ml}$ of glacial acetic acid and extracted with $25 \mathrm{ml}$ of toluene by shaking vigorously on a platform shaker for $15 \mathrm{~min}$. The sample was transferred to a separatory funnel and the lower aqueous layer run off. The water was further separated by centrifugation and the toluene extract sealed and frozen until analysis. Where necessary the extracts were preconcentrated prior to analysis. Aliquots were treated with $1 \mathrm{M}$ sodium hydroxide and reanalyzed to determine tributyltin (Cleary 1991).

Trace metals were removed from seawater by solvent extraction (Danielsson et al, 1982). Metal carbamate complexes were extracted from seawater (buffered to $\mathrm{pH}$ 5) with ammonium pyrrollidine dithiocarbamate (APDC) and diethylammonium diethyldithiocarbamate (DDDC) into 1,1,2-trichloro-1,2,2-trifluoroethane (Freon TF) and back-extracted into $0.3 \mathrm{M}$ nitric acid prior to analysis by graphite furnace atomic absorption spectrophotometry.

On-board facilities were not ideal for chemical extraction since there were no clean working areas or fume hoods available, but as the intention was to perform water chemistry and bioassays simultaneously, these limitations were accepted.

\section{RESULTS}

\section{Comparison of microlayer collection methods}

At Stn 4, and in Wilhelmshaven, microlayer samples were collected with both the screen and drum samplers and analyzed for 5 different metals, total organotin and tributyltin yielding a total of 9 concurrent comparisons (Table 2). There was no significant difference (2-sample $t$-test assuming independent samples with unequal variances, $t=0.26$, $\mathrm{df}=15$ ) in the log-transformed concentrations of metals collected by the screen or the drum. At Wilhelmshaven, 7 concurrent samples were collected using the screen and glass plate. No significant difference $(t=0.28, \mathrm{df}=11)$ in the log-transformed metal concentrations were found in microlayer samples collected using these 2 techniques.

Twelve of the microlayer samples collected concurrently with the screen and the drum were tested by either the oyster larvae or copepod bioassays. Although there was no significant difference $(t=-1.02, \mathrm{df}=5)$ in toxicity between samples collected using the 2 techniques, the drum samples tended to be somewhat more toxic than the screen samples (Table 3 ). This may express the fact that drum-collected samples are often thinner, more chemically enriched, and less diluted with underlying water than screen samples.

Since chemical concentrations in microlayer samples did not differ significantly according to collection techniques, screen, drum and plate-collected samples were pooled for subsequent comparison and discussion below.

\section{Comparison of microlayer and bulkwater}

With the exception of $\mathrm{Ni}$, metal concentrations were much greater in the microlayer than in near-surface bulkwater at all stations sampled (Table 2). Mean and maximum enrichment factors (microlayer concentration/bulkwater concentration) were: $\mathrm{Cd}>1.7$ to $2.7 ; \mathrm{Ni}$ 0.9 to $1.7 ; \mathrm{Cu} 4.7$ to $8.8 ; \mathrm{Pb} 3.2$ to $6.1 ; \mathrm{Zn} 1.9$ to 4.7 ; organotins 8.9 to 16.5 ; and tributyltin 6.5 to 10.7 . Mercury concentrations in unfiltered samples at Stn 4

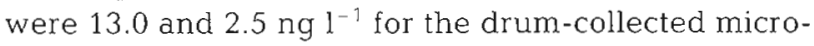
layer and $10 \mathrm{~m}$ subsurface bulkwater, respectively.

Based on pooled screen and drum data, microlayer samples were generally more toxic $156 \pm 8 \%$ mean survival or growth) than bulkwater samples $(71 \pm 6 \%$ mean survival or growth), although the difference was not statistically significant. Toxicity of drum samples alone (not pooled with screen samples) was $38 \pm 12 \%$ of controls - an even larger and significant difference $(t=-2.37, \mathrm{p}=0.035, \mathrm{df}=12$ ) compared to bulkwater (Table 3) 


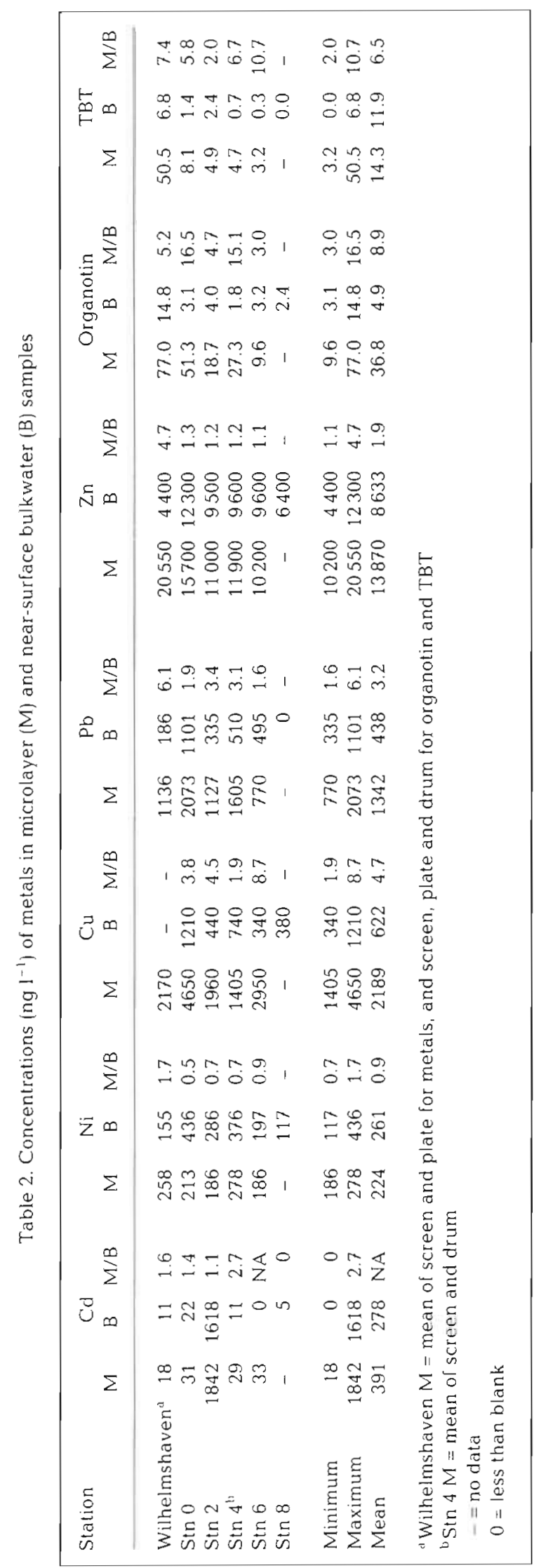

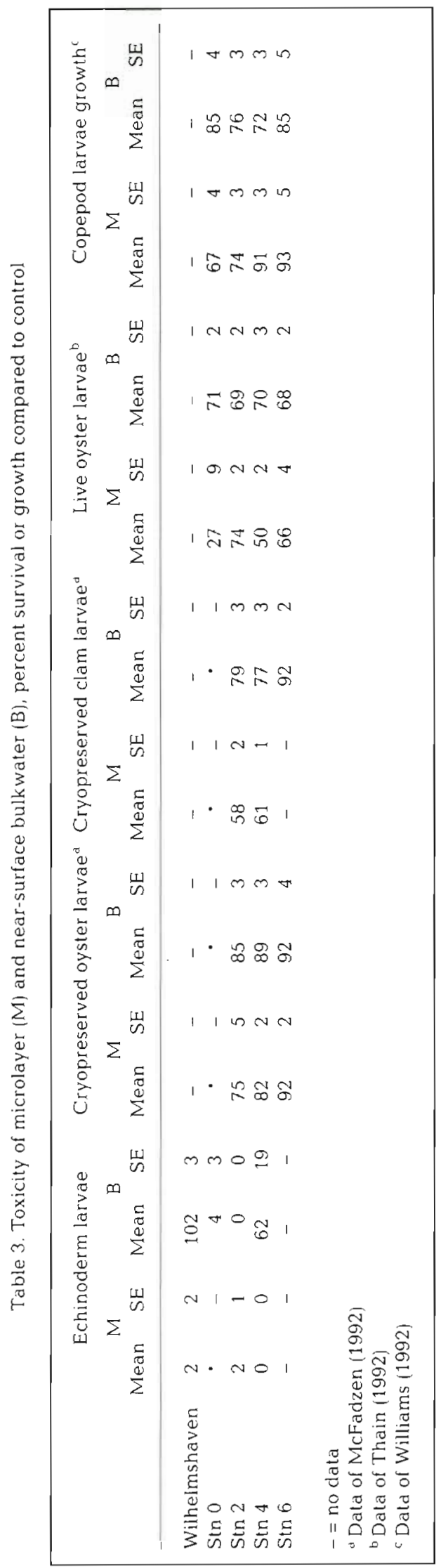




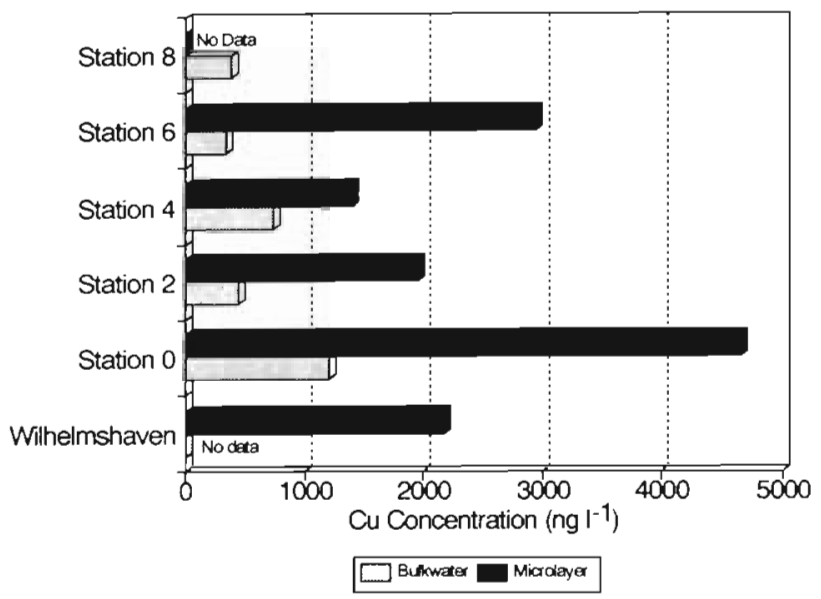

Fig. 2. Concentrations of copper in the microlayer and nearsurface bulkwater of the North Sea

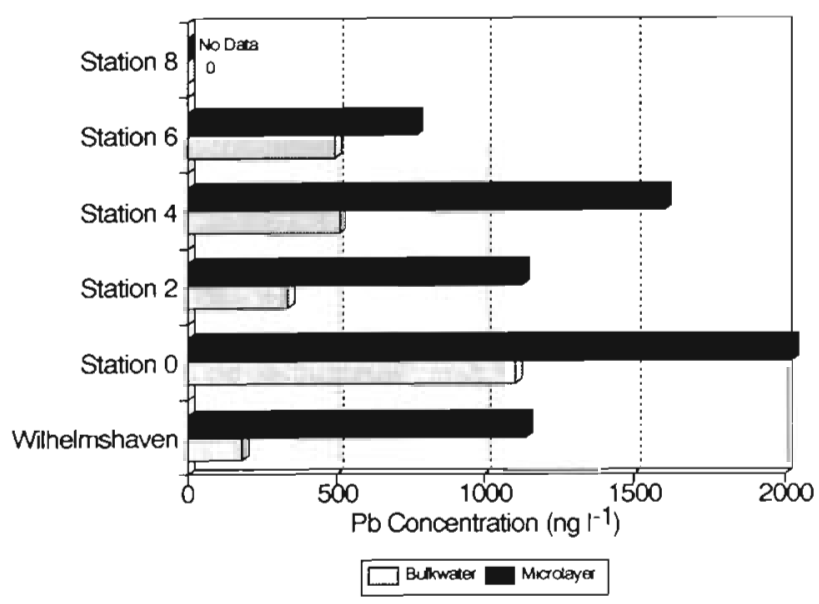

Fig. 3. Concentrations of lead in the microlayer and nearsurface bulkwater of the North Sea

\section{Comparison of stations}

In general, compared to typical nearshore values elsewhere, metal concentrations in both the microlayer and bulkwater tended to be very high at $\operatorname{Sin} 0$, moderately high at Stns 2 to 6 , and near baseline levels at Stn 8 (Table 2; Figs. 2 to 5). At Wilhelmshaven concentrations of $\mathrm{Zn}$, organotins and tributyltin were very high with microlayer concentrations of 20550,77 , and $50.5 \mathrm{ng} \mathrm{l}^{-1}$, respectively.

Microlayer and bulkwater were evaluated for toxicity at 5 stations using 5 different toxicity tests (Table 3). Toxicity in several cases was higher nearshore and decreased with increasing distance offshore in both the microlayer and near-surface bulkwater. This trend was, perhaps, most clearly shown by the copepod

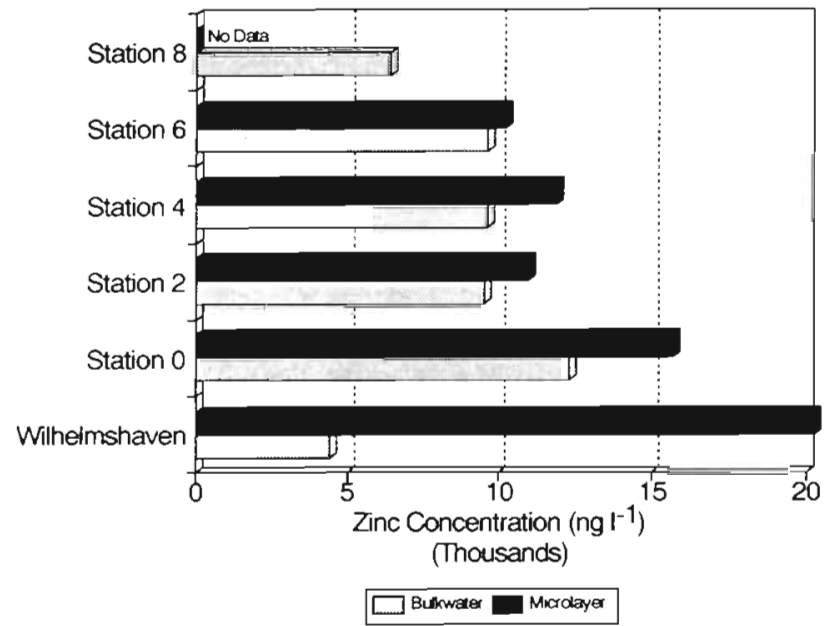

Fig. 4. Concentrations of zinc in the microlayer and nearsurface bulkwater of the North Sea

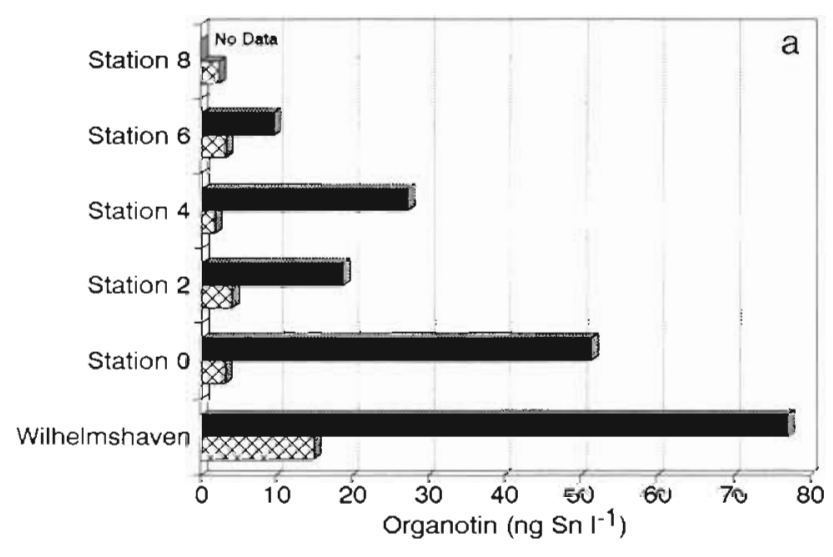

EQX Buhwater Microlayer

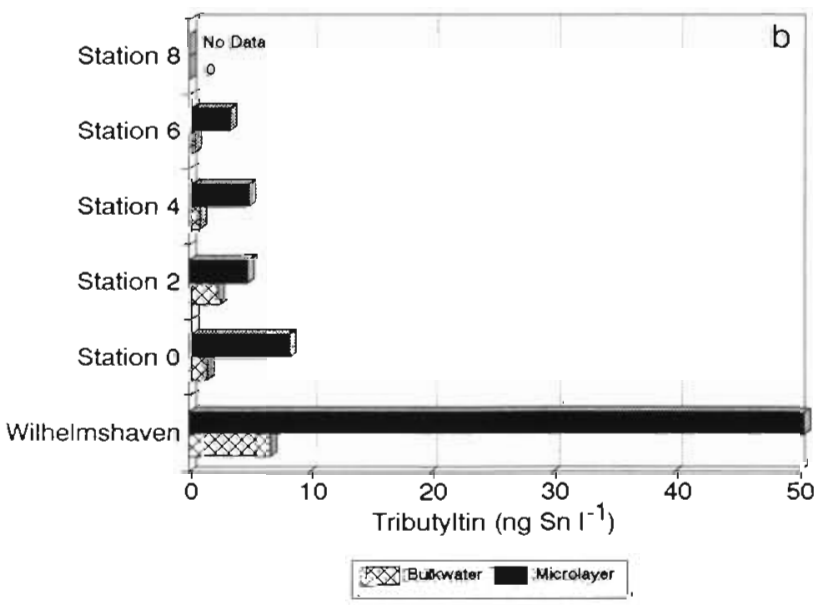

Fig. 5. Concentrations of (a) organotin and (b) tributyltin in the microlayer and near-surface bulkwater of the North Sea 


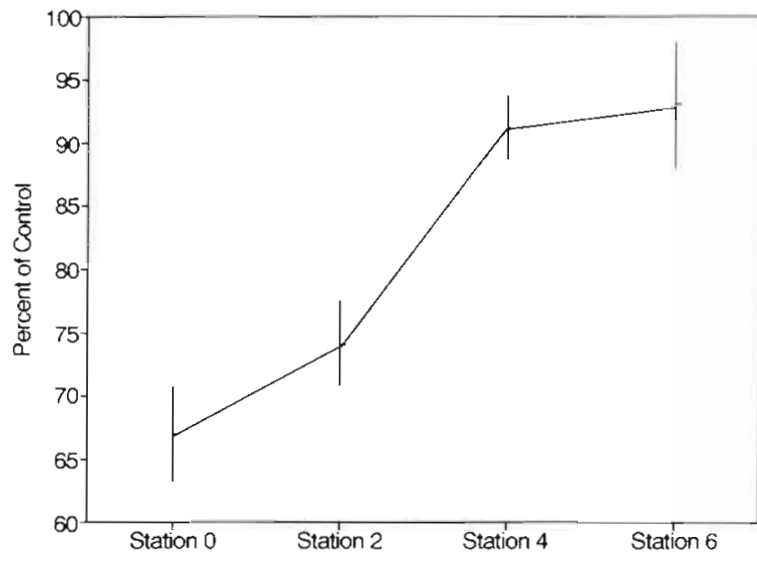

Fig. 6. Growth of the copepod Tisbe battagliai (means \pm SE) incubated in collected microlayer samples is reduced nearshore and increases further offshore (data of Williams 1992)

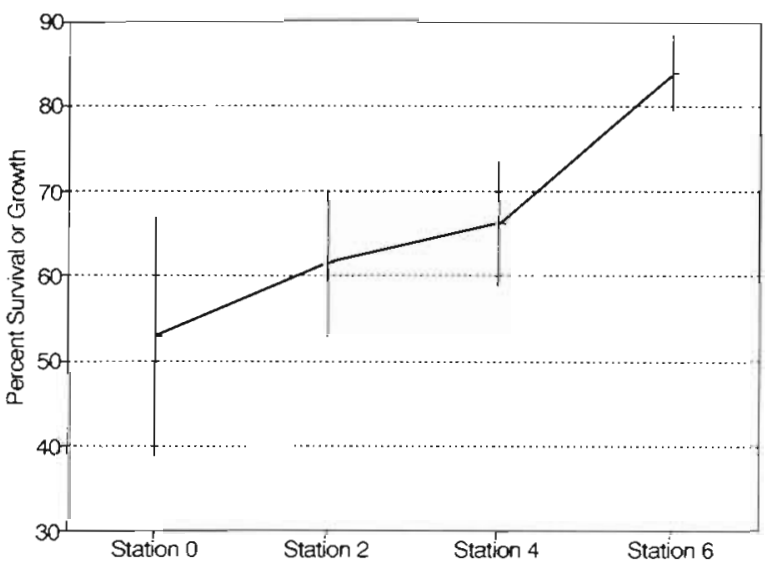

Fig. 7. Pooling of all microlayer and bulkwater samples tested, using a variety of bioassays, indicates that toxicity is generally high nearshore and decreases at stations further offshore. Means $\pm \mathrm{SE}$

growth tests using microlayer (Fig. 6), obtained by pooling the results from the screen and drum sampler.

As evaluated by the echinoderm larval development test all samples, except the bulkwater sample from Wilhelmshaven, showed significant toxicity compared to the control clean seawater samples (Table 3). Both microlayer and bulkwater were very toxic nearshore (Stns 0 \& 2). Further offshore ( $\operatorname{Stn} 4$ ) microlayer remained very toxic, but bulkwater was only slightly toxic.

A pooled group of 36 tests (Table 3) indicates that survival or growth increased from $53 \%( \pm 14 \%, N=5)$ of controls nearshore at Stn 0 to $84 \%( \pm 4.5 \%, \mathrm{~N}=7)$ at Stn 6 offshore (Fig. 7). Stn 6 of fshore was significantly less toxic overall than any of the other stations (2sample $t$-test $90 \%$ confidence interval).

In oyster larvae exposed to both screen-collected microlayer and bulkwater samples, survival was inversely related to the concentration of organotin in the

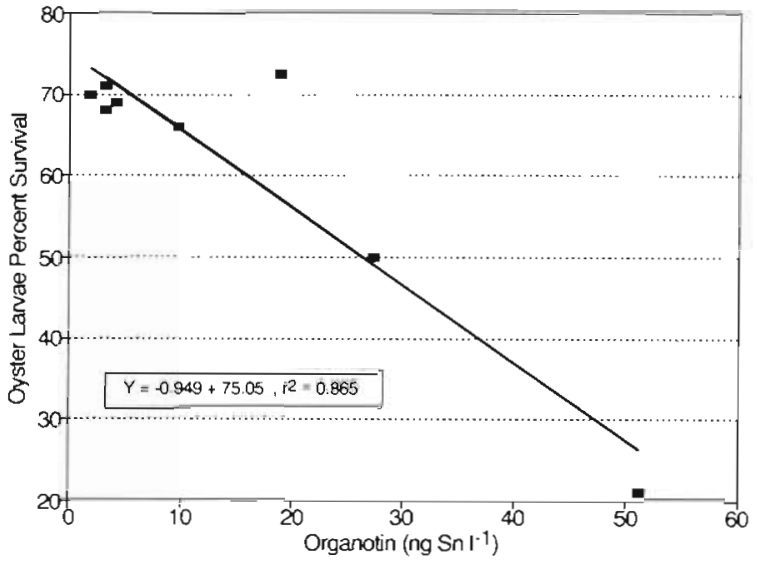

Fig. 8. Crassostrea gigas. Survival of oyster larvae decreased with increasing concentrations of organotin. Data includes both microlayer and bulkwater samples (see also Thain 1992)

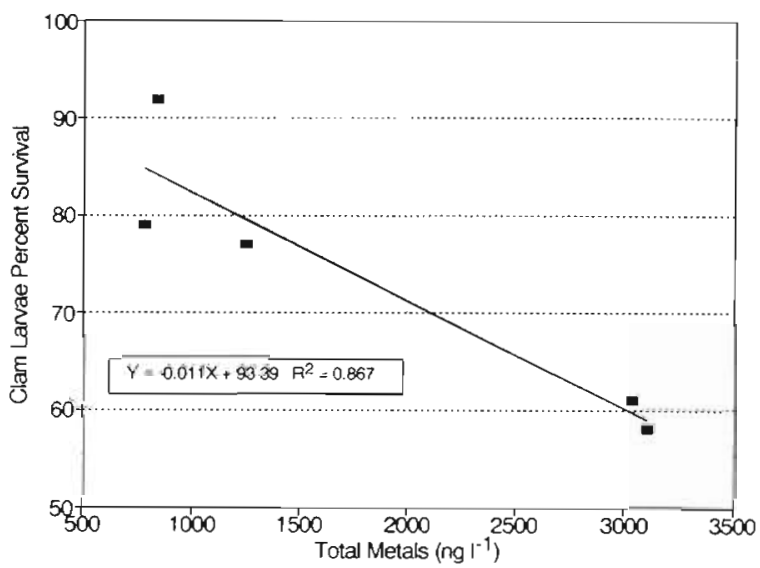

Fig. 9. Tapes philippinarum. Survival of clam larvae decreased with increasing concentrations of metals (total $=\mathrm{Cu}+$ $\mathrm{Pb}+$ organotin). Data includes both microlayer and bulkwater samples (see also McFadzen 1992)

samples (Fig. 8). Similarly, survival of clam larvae decreased with increasing concentrations of metals (total $\mathrm{Cu}, \mathrm{Pb}$ and organotin) in the collected samples (Fig. 9). Correlation between contaminant concentrations and toxicity does not prove cause and effect (Figs. 8 \& 9). However, our data suggest that metals, particularly the high concentrations of organotins, could be responsible for much of the observed toxicity.

\section{DISCUSSION}

Microlayer sampling techniques have been compared by Hühnerfuss (1981). Our results indicate little difference in the chemistry of samples collected with the drum, screen or glass plate. However, the rotating drum technique has several advantages to recommend it for routine monitoring of sea surface contamination. It collects a sample which is quite representative of the 
thin (20 to $60 \mathrm{~mm}$ ) chemically-enriched surface layer without the dilution with subsurface water inherent in the screen technique. It is less tedious than the other techniques since a volume of several litres, necessary for many types of chemical analyses, can be collected within 10 to 60 min.

Metal enrichments in the microlayer compared to the bulkwater (Table 2) were similar to those measured in previous studies (Dehairs et al. 1982) and generally agree with those predicted by an atmospheric deposition sea-surface fractionation model (Hardy et al 1985b). Measured bulkwater concentrations of other metals generally agreed with literature values and other workshop data (Kremlin \& Hydes 1988, Sünderman \& Degens 1989, Cofino et al. 1992), but for $Z_{n}$ they were higher. This may be due to shipboard contamination. At Stn $2 \mathrm{Cd}$ values were unaccountably high in both microlayer and bulkwater. High microlayer enrichments of organotin have been reported previously from estuarine and nearshore sites (Hall et al. 1986, Cleary 1991). However, we report, for the first time, high concentrations of organotin in the microlayer of offshore sites quite remote from coastal ship harbours.

These data suggest that a zone of toxic surface water, with contaminant levels exceeding water quality standards, extends from the shore outward some 100 to $200 \mathrm{~km}$ offshore. Microlayer concentrations of TBT and Cu exceed both the UK EQS value of $2 \mathrm{ng}$ TBT ${ }^{-1}$ and the U.S. EPA chronic water quality limit of $2.9 \mathrm{mg} \mathrm{Cu} \mathrm{l}^{-1}$. Stations less than $100 \mathrm{~km}$ from Cuxhaven at the mouth of the Elbe River (Stns 0, 2 \& 4) were generally toxic, while samples at Stn 6 about $284 \mathrm{~km}$ from Cuxhaven were not significantly toxic.

Does microlayer contamination pose a significant threat to large populations of marine organisms? Floating embryos of plaice Pleuronectes platessa, cod Gadus morhua and whiting Merlangius merlangus, collected from the surface of the North Sea, demonstrated a very high incidence ( 5 to $26 \%$ ) of abnormalities (Dethlefsen et al. 1985), possibly as a result of exposure to surface microlayer contamination. Corroborative data are given by Cameron \& Berg (1992). Given the high concentrations of contaminants in the microlayer and the probability of toxic effects, we believe present levels of microlayer contamination could pose a threat to fisheries recruitment in the North Sea.

Acknowledgements. This study was made possible through financial support of the Intergovernmental Oceanographic Commision of UNESCO and the Department of the Environment, UK. The tireless organizational efforts of Dr A. R. D. Stebbing made the overall interdisciplinary North Sea studies possible. We especially thank Ian McFadzen, Tim Williams and John Thain who conducted many of the toxicity bioassays and supplied data critical to this study. Jan Bening and Dr Ludwig Karbe (University of Hamburg), along with the crew of the RV 'Valdivia', provided vital logistical support Dr E. Rachor (Alfred Wegner Institute for Polar and Marine Research) provided willing facility support. Mercury concentrations were determined by Georg Schupfner and Rainer Zeitner, University of Hamburg. We appreciate the excellent technical assistance in field sampling and laboratory analysis provided by Mary Brinsely and Sherry Chilcutt.

\section{LITERATURE CITED}

APHA (1989). Toxicity test procedures for the calanoid copepod, Arcatia tonsa (Dana). American Public Health Association. Standard Methods for the Examination of Water and Wastewater, 17 th edn. p. 8-85 to 8-90

ASTM (1980). Standard practice for conducting acute toxicity tests with larvae of four species of bivalve molluscs. American Society for Testing and Materials. Annual Book of ASTM Standards. Report \# E-724-80, p. 1-17

Baier, R. E., Goupil, D. W., Perlmutter, S., King, R. (1974) Dominant chemical composition of sea-surface films, natural slicks, and foams. J. Rech. Atmos. 8: 571-600

Calabrese, A. (1984). Ecotoxicological testing with marine molluscs. In: Persoone, G., Jaspers, E., Claus, C. (eds.) Ecotoxicological testing for the marine environment, Vol. 1 State Univ. Ghent and Inst. Mar. Scient. Res. Belgium, p. $455-477$

Cameron, P., Berg, J. (1992). Morphological and chromosomal aberrations during embryonic development in dab Limanda limanda. Mar. Ecol. Prog. Ser. 91: 163-169

Chapman, P. M., Morgan, J. D. (1983). Sediment bioassays with oyster larvae. Bull. environ. Contam. Toxicol. 31: $438-444$

Cleary, J. J. (1991). Organotin in the marine surface microlayer and subsurface waters of southwest England; relation to toxicity thresholds and the U.K. environmental quality standard. Mar. environ. Res. 32: 213-222

Cofino, W. P., Smedes, F., de Jong, S. A., Abarnou, A., Boon, J. P., Oostingh, I., Davies, I. M., Klungsøyr, J, Wilhelmsen, S., Law, R. J., Whinnett, J. A., Schmidt, D., Wilson, S. (1992). The chemistry programme. Mar. Ecol. Prog. Ser 91: $47-56$

Cross, J. N., Hardy, J. T., Hose, J. E., Hershelman, G. P., Antrim, L. D., Gossett, R. W., Crecelius, E. A. (1987). Contaminant concentrations and toxicity of sea-surface microlayer near Los Angeles, California. Mar. environ. Res. 23: 307-323

Danielsson, L. D., Magnusson, B., Westerlund, S., Zhang, K. (1982). Trace metal determinations in estuarine waters by electrothermal atomic absorption spectrometry after extraction of dithiocarbamate complexes into Freon. Anal. Chim. Acta. 144: 183-188

Dehairs, F., Dedeurwaerder, H., Decadt, G., Dejonghe, M., Gillian, G., Baeyens, W (1982). The atmosphere as a transport route of heavy metals to the sea. Marine Environmental Quality Committee. C.M./ICES, E36: 59-84

Dethlefsen, V., Cameron, P., von Westernhagen, H. (1985). Untersuchungen über die Häufigkeit von Mißbildungen in Fischembryonen der südlichen Nordsee. Inf. Fischwirtsch. 32: 22-27

Eldridge, P. J., Berry, F. H., Miller, M. C. (1978). Diurnal variations in catches of ichthyoneuston by the Boothbay neuston net off Charleston, South Carolina. Fish. Bull. U.S. 76 (1): $295-297$

Garrett, W. D. (1965). Collection of slick-forming materials from the sea surface. Limnol. Oceanogr. 10: 602-605 
Hall, L. W. Jr, Lenkevich, M. J., Hall, W. S., Pinkney, A. E., Bushong, S. J. (1986). Monitoring organotin concentrations in Maryland waters of Chesapeake Bay. In: Proceedings Organotin Symposium, Vol. 4. Oceans 86. Marine Technology Society. Washington, D.C., p. $1275-1279$

Hardy, J T (1982). The sea surface microlayer, biology, chemistry, and anthropogenic enrichment. Prog. Oceanogr. 11: $307-328$

Hardy, J. T. (1991). Where the sea meets the sky. Natural History, May, p. 59-65

Hardy, J. T., Apts, C. W., Crecelius, E. A., Bloom, N. S. (1985a). Sea-surface microlayer metals enrichments in an urban and rural bay. Estuar. coast. Shelf Sci. 20: 299-312

Hardy, J. T., Apts, C. W., Crecelius, E. A., Fellingham, G. W. (1985b). The sea-surface microlayer: fate and residence time of atmospheric metals. Limnol. Oceanogr. 30(1): 93-101

Hardy, J. T., Coley, J. A., Antrim, L. D., Kiesser, S. L. (1988). A hydrophobic large-volume sampler for collecting aquatic surface microlayers: characterization and comparison to the glass plate method. Can. J. Fish. Aquat. Sci. 45 (2): $822-826$

Hardy, J. T., Crecelius, E. A., Antrim, L. D., Kiesser, S. L, Broadhurst, V. L., Boehm, P. D., Steinhauer, W. G. (1990). Aquatic surface contamination in Chesapeake Bay. Mar. Chem. 28: $333-351$

Hardy, J. T., Crecelius, E. A., Apts, C. W., Gurtisen, J. M. (1987a). Sea-surface contamination in Puget Sound: Part II. Concentration and distribution of contaminants. Mar. environ. Res. 23: 251-271

Hardy, J. T., Kiesser, S. L., Antrim, L. D., Stubin, A. I., Kocan, R., Strand, J. A. (1987b). The sea-surface microlayer of Puget Sound: Part I. Toxic effects on fish eggs and larvae. Mar. environ. Res. 23: 227-249

Hempel, G., Weikert, H. (1972). The neuston of the subtropical and boreal Northeastern Atlantic Ocean, a review. Mar. Biol. 13: 70-88

Hinegardner, R. T (1967). Echinoderms. In: Wilt, F. H., Wessels, N. K. (eds.) Methods in developmental biology. Thomas Y. Crowell Co., New York, p. 139-155

Hühnerfuss, H. (1981). On the problem of sea-surface film sampling: a comparison of 21 microlayer, 2 multilayer, and
4 selected subsurface-samplers - Part 1 Sonderdruck aus Meerestechnik 12 (Nr. 5) S: 136

Kocan, R. M., von Westernhagen, H., Landolt, M. L., Furstenberg, G. (1987). Toxicity of sea-surface microlayer: effects of hexane extract on Baltic herring (Clupea harengus) and Atlantic cod (Gadus morhua) embryos. Mar. environ. Res. 23(4): 291-305

Kremling, K., Hydes, D. (1988). Summer distribution of dissolved $\mathrm{Al}, \mathrm{Cd}, \mathrm{Co}, \mathrm{Cu}, \mathrm{Mn}$ and $\mathrm{Ni}$ in surface waters around the British Isles. Cont. Shelf Res. 8: 89-105

McFadzen, I. R. B. (1992). Growth and survival of cryopreserved oyster and clam larvae along a pollution gradient in the German Bight. Mar. Ecol. Prog. Ser. 91 : $215-220$

Oshida, P. S. (1977). Toxicity of a chlorinated benzene to sea urchin embryos. In: Southern California Coastal Water Research Project, Annual Report, p. 187-192

Shanks, A. L. (1983). Surface slicks associated with tidally forced internal waves may transport pelagic larvae of benthic invertebrates and fishes shoreward. Mar. Ecol. Prog. Ser. 13: 311-315

Stebbing, A. R. D. (1991). ICES/IOC Workshop on the biological effects of contaminants in the North Sea: preliminary report. Plymouth Marine Laboratory, Plymouth, UK

Sündermann, J., Degens, E. T. (1989). The North Sea. Water Exchange and Pollution. Summary of Research Funded by the Federal Ministry of Research and Technology (BMFT). University of Hamburg, Institut für Meereskunde

Thain, J. (1992). Use of the oyster Crassostrea gigas embryo bioassay on water and sediment elutriate samples from the German Bight. Mar. Ecol. Prog. Ser. 91: 211-213

Westernhagen, H., Landolt, M., Kocan, R., Janssen, D., Kremling, K. (1987). Toxicity of sea surface microlayer: effects on herring and turbot embryos. Mar. environ. Res. 23 (4): $273-290$

Williams, T D. (1992). Survival and development of copepod larvae Tisbe battagliai in surface microlayer, water and sediment elutriates from the German Bight. Mar. Ecol. Prog. Ser. 91: 221-228

Zaitsev, Y P. (1971). Marine neustonology (Translated from Russian). National Marine Fisheries Service, NOAA and National Science Foundation, National Technical Information Service, Springfield, Virginia 